\title{
Pengembangan Panduan Pelatihan Empati Menggunakan Teknik Sinema Edukasi untuk Mencegah Perilaku Bullying Siswa Sekolah Menengah Pertama
}

\author{
Vesti Dwi Cahyaningrum ${ }^{1}$, Dany Moenindyah Handarini², Irene Maya Simon² \\ ${ }^{1}$ Program Studi Bimbingan dan Konseling, Fakultas Keguruan dan Ilmu Pendidikan, \\ Universitas Nahdlatul Ulama Sunan Giri, Jl. Jend. Ahmad Yani No.10, Bojonegoro, Jawa Timur, Indonesia \\ 62115 \\ ${ }^{2}$ Jurusan Bimbingan dan Konseling, Fakultas Ilmu Pendidikan, Universitas Negeri Malang, \\ J1. Semarang No. 5, Malang, Jawa Timur, Indonesia 65145 \\ E-mail: vestidwibk@yahoo.com
}

Artikel diterima: 29 Agustus 2017; direvisi: 3 Juli 2018; disetujui: 9 Agustus 2018

\begin{abstract}
This study aimed to develop a training guide of empathy attitude skills as prevention of bullying behavior on junior high school students. The method was a research and development model. The subjects of the research were guidance and counseling experts; educational technology expert; and school counselors. The instrument was the empathy attitude skill scale for students; expert assessment instruments and counselor assessment instruments. Data from the assessment results of guidance and counseling expert; educational technology expert; and three school counselors in three different schools in Malang City showed that the developed products were acceptable and feasible to be used to improve empathy skills as prevention of bullying behavior of junior high school students.
\end{abstract}

Keywords: training guide; empathy; bullying; junior high school

\begin{abstract}
Abstrak: Penelitian ini bertujuan untuk mengembangkan panduan pelatihan keterampilan sikap empati sebagai pencegahan perilaku bullying siswa sekolah menengah pertama (SMP). Metode yang digunakan dalam penelitian ini ialah model penelitian dan pengembangan. Subjek uji coba penelitian ini adalah ahli bimbingan dan konseling (BK); ahli teknologi pendidikan (TEP); dan konselor sekolah. Instrumen yang digunakan adalah skala keterampilan sikap empati untuk siswa; instrumen penilaian ahli dan instrumen penilaian konselor. Data hasil penilaian ahli BK; ahli TEP; dan tiga konselor sekolah di tiga sekolah yang berbeda di Kota Malang menunjukkan bahwa produk yang dikembangkan dapat diterima dan layak digunakan untuk meningkatkan keterampilan sikap empati sebagai pencegahan perilaku bullying siswa SMP.
\end{abstract}

Kata kunci: panduan pelatihan; empati; bullying; siswa SMP

Masa remaja merupakan masa yang paling rawan dalam pergaulan, dimana emosi pada masa ini sangat labil (Ediati, 2015). Kondisi psikis remaja sangat labil karena masa ini merupakan fase pencarian jati diri. Masa pencarian jati diri di kalangan remaja, dapat menimbulkan permasalahanpermasalahan yang berpotensi membentuk pribadi kurang baik karena kurangnya bimbingan dari segi akademik; individu; ataupun juga dari kondisi keluarga yang kurang memberikan bimbingan terhadap seorang anak atau peserta didik. Salah satunya bentuk kepribadian yang kurang baik adalah bullying (Hurlock, 1999). Bullying adalah tindakan bermusuhan yang dilakukan secara sadar dan disengaja, bertujuan untuk menyakiti seperti menakuti melalui ancaman agresi dan menimbulkan 
teror (Coloroso, 2007). Pelaku bullying memiliki karakteristik untuk melakukan dominasi terhadap orang lain melalui kekerasan, dan mereka menunjukkan sedikit atau bahkan tidak menunjukkan empati sama sekali pada korban mereka (Papalia, Olds, \& Feldman, 2007).

Dalam fenomena bullying, salah satu karakteristik pelakunya adalah memiliki empati yang rendah terhadap para korban (Rigby, 2002). Hal ini tercermin dari rendahnya kepedulian pelaku terhadap konsekuensi emosional yang dapat mereka berikan pada orang lain serta rendahnya kemampuan untuk turut merasakan konsekuensi emosional tersebut (Arsenio \& Lemerise, 2001; Gini, Albiero, Benelli, \& Altoè, 2007). Berdasarkan hasil penelitian tersebut, pengembangan empati dinilai sebagai komponen penting dalam penerapan program yang bertujuan untuk mengurangi perilaku agresif pada umumnya dan bullying pada khususnya (Miller \& Eisenberg, 1988).

Di Kota Malang, siswa SMP sebagian besar memiliki empati yang rendah. Hal ini diketahui lewat penelitian awal yang dilakukan peneliti. Dalam penelitian awal, peneliti mengukur tingkat keterampilan empati siswa SMP dengan mengambil sampel secara acak. Sejumlah 165 siswa yang menjadi sampel diminta mengisi instrumen skala empati yang sudah divalidasi. Secara rinci hasil penelitian menunjukkan $1,21 \%$ siswa memiliki empati sangat rendah; $45,45 \%$ memiliki empati rendah; 35,15\% memiliki empati sedang; $15,15 \%$ memiliki empati tinggi; dan 3,03\% memiliki empati sangat tinggi. Hal ini berarti banyak siswa memiliki kecenderungan tinggi untuk melakukan bullying.

Panduan pelatihan empati merupakan produk yang dapat digunakan dalam membantu siswa meningkatkan empatinya. Di dalam panduan tersebut, film digunakan sebagai media untuk meningkatkan empati siswa. Film merupakan sebuah media yang dapat meningkatkan kognitif maupun afektif (Arsyad, 2016) dan empati seseorang (Auliyah \& Flurentin, 2016; Limarga, 2017; Mufiqoh, Sugiharto, \& Anni, 2018). Dengan menggunakan beberapa film tentang bullying dalam pelatihan, siswa akan mengamati pengalaman-pengalaman yang dialami tokoh dalam film, dan diharapkan siswa mampu empati pada tokoh tersebut. Pengalaman tokoh tersebut diharapkan dapat menjadi cermin bagi siswa di kemudian hari ketika dia juga mengalami masalah yang sama dengan tokoh dalam film. Dengan mengamati, siswa akan terbantu untuk merasakan apa yang dirasakan oleh tokoh, secara tidak langsung keterampilan sikap empati siswa muncul dengan sendirinya ketika melihat apa yang dirasakan oleh tokoh dalam film. Dengan kematangan kognitifnya, siswa akan dapat menggunakan kemampuan berpikirnya untuk melakukan analisa terhadap masalah yang dialami oleh tokoh dalam film.

Berdasarkan berbagai ulasan adanya masalah mengenai bullying, kami melaksanakan penelitian dan pengembangan panduan pelatihan sikap empati sebagai upaya pencegahan perilaku bullying siswa SMP.

\section{METODE}

Metode yang digunakan dalam penelitian ini mengadaptasi model prosedural penelitian dan pengembangan Gall, Borg, \& Gall (1996). Alur kerja penelitian seperti yang digambarkan pada gambar 1 memiliki tiga tahap. Tahap pertama merupakan tahap persiapan yang terdiri dari dua kegiatan, yaitu: melakukan penelitian awal dan pengumpulan informasi serta perencanaan pengembangan. Penelitian awal dengan melancarkan survei skala sikap empati dilaksanakan di: SMP Negeri 8 (mewakili Kecamatan Klojen); SMP Negeri 26 (mewakili Kecamatan Lowokwaru); SMP Negeri 20 (mewakili Kecamatan Blimbing); SMP Negeri 12 (mewakili Kecamatan Sukun) dan SMP Negeri 10 (mewakili Kecamatan Kedungkandang) mulai bulan Desember 2015 hingga Februari 2016.

Tahap kedua adalah tahap pelaksanaan pengembangan produk. Kegiatan yang dilakukan pada tahap kedua adalah: menyusun kisi-kisi isi produk, menentukan desain produk, pembuatan produk hingga menghasilkan draf produk kasar yang terdiri dari: buku panduan pelatihan untuk konselor dan media digital video disc (DVD) pelatihan untuk konselor. Setelah draf kasar produk jadi, pengembangan dilanjutkan ke tahap ketiga. 


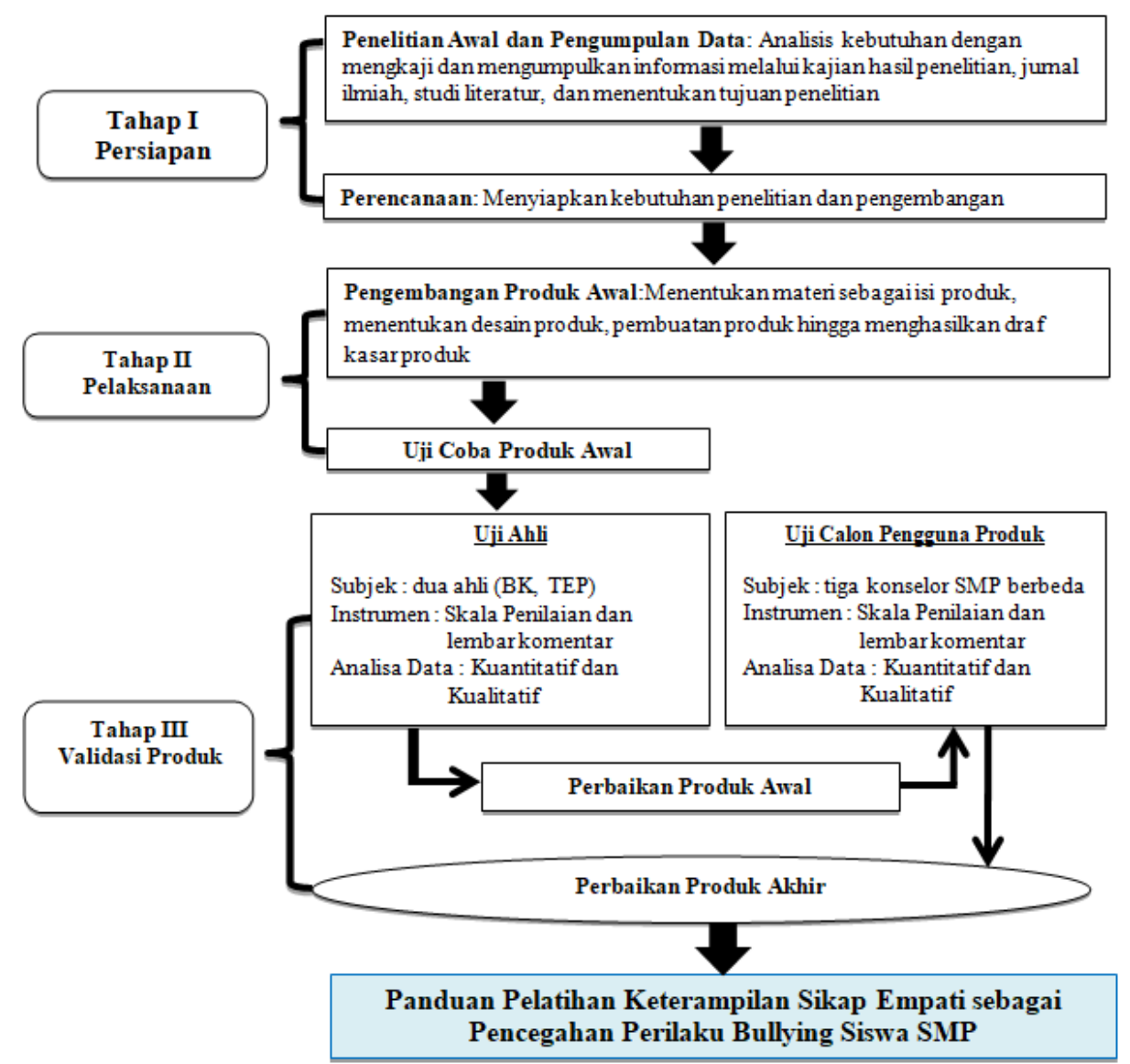

\section{Gambar 1 Alur Kerja Penelitian dan Pengembangan}

Tahap ketiga adalah tahap validasi produk. Tahap validasi dimulai lewat uji coba ahli. Ahli yang dilibatkan pada tahap ini adalah ahli BK (Dosen Jurusan BK) dan ahli TEP (Dosen Jurusan TEP). Uji ahli menghasilkan skala penilaian angka dan penilaian secara deksriptif. Hasil dari penilaian uji ahli tersebut dijadikan dasar perbaikan produk. Setelah diperbaiki, produk diujikan pada calon pengguna. Calon pengguna produk yang dilibatkan adalah Konselor SMP Negeri 8 Malang; Konselor SMP Negeri 26 Malang; dan Konselor SMP Negeri 12 Malang. Uji calon pengguna juga menghasilkan penilaian skala angka dan penilaian deskriptif. Hasil penilaian kemudian digunakan sebagai dasar penyempurnaan produk.

Secara keseluruhan, data yang didapatkan dari uji coba produk berupa skala angka (kuantitatif) dan penilaian deskriptif berupa saran dan komentar terkait produk (kualitatif) dianalisis menggunakan teknik percentage of agreements. Teknik percentage of agreements adalah analisis perbutir berdasarkan kesepakatan subjek penilaian terhadap skala angka penilaian untuk aspek kegunaan; kemenarikan; ketepatan; dan kepatutan produk.

\section{HASIL}

Produk yang dihasilkan dalam penelitian dan pengembangan ini adalah Panduan Pelatihan Empati untuk mencegah perilaku bullying yang terdiri dari: buku panduan pelatihan untuk konselor dan media pelatihan empati untuk mencegah perilaku bullying siswa SMP dalam bentuk DVD. Isi pada buku panduan pelatihan adalah: bagian I mengulas latar belakang dan tujuan pelatihan, bagian II merupakan petunjuk umum langkah-langkah yang harus dipersiapkan konselor sebelum memberikan pelatihan, dan bagian III merupakan prosedur pelatihan yang menguraikan rumusan pelaksanaan spesifik tentang kegiatan yang akan dilakukan konselor pada setiap pertemuan dalam pelatihan. 
Selain buku pedoman, produk yang dihasilkan adalah media pelatihan empati untuk mencegah perilaku bullying siswa SMP dalam bentuk DVD. DVD tersebut berisi folder-folder untuk setiap pertemuan pelatihan. Folder-folder tersebut berisi film dan media untuk kegiatan pelatihan pencegahan perilaku bullying yang sesuai dengan topik pelatihan. Media ini hanya dapat diputar pada DVD room drive pada komputer pribadi dan laptop.

Agar produk yang dikembangkan berguna; menarik; tepat; dan patut, produk diujikan pada ahli dan calon pengguna. Dari uji ahli dan calon pengguna, didapatkan data berupa skala angka (kuantitatif) dan penilaian deskriptif berupa saran serta komentar terkait produk (kualitatif).

\section{Penilaian Kuantitatif}

Data angka merupakan data yang diperoleh dari penilaian ahli berdasarkan isian angket skala penilaian. Skala penilaian ini merupakan alat ukur dengan empat indikator penilaian yaitu: kegunaan; kelayakan; ketepatan; dan kepatutan. Aspek kegunaan menjabarkan butir-butir berkaitan dengan indikator faedah produk untuk pengguna indikator intervensi teknik pada produk. Hasil penilaian kedua ahli dan ketiga calon pengguna terhadap produk menunjukkan persentase kesepakatan berada pada rentangan $66,7 \%-100 \%$ dengan skala penilaian angka $3-4$, yang artinya masuk pada kategori kesepakatan sangat tinggi terhadap kebergunaan produk.

Aspek selanjutnya adalah kelayakan produk. Aspek penilaian ini menjabarkan butir-butir terkait kelayakan isi produk. Hasil penilaian kedua ahli dan ketiga calon pengguna terhadap produk menunjukkan persentase kesepakatan yang berada pada rentangan $66,7 \%-100 \%$ dengan skala penilaian angka 3-4, yang artinya masuk pada kategori kesepakatan sangat tinggi terhadap kelayakan produk.

Penilaian aspek ketepatan menjabarkan butir-butir terkait ketepatan keberadaan produk; ketepatan rancangan kegiatan produk; ketepatan isi buku materi; ketepatan penggunaan bahasa dan ketepatan intervensi pada produk. Hasil penilaian kedua ahli dan ketiga calon pengguna terhadap produk menunjukkan persentase kesepakatan pada rentangan $66,7 \%-100 \%$ dengan skala penilaian angka 3-4 yang artinya masuk pada kategori kesepakatan sangat tinggi terhadap ketepatan produk.

Aspek terakhir yaitu kepatutan yang menjabarkan butir-butir terkait persyaratan kompetensi calon pengguna produk; standar kode etik; dan pertanggungjawaban secara komprehensif. Hasil penilaian ketiga ahli dan ketiga calon pengguna terhadap produk menunjukan persentase kesepakatan pada rentangan $66,7 \%-100 \%$ dengan skala penilaian angka 3-4 yang berarti masuk pada kategori kesepakatan sangat tinggi terhadap kepatutan produk.

\section{Penilaian Kualitatif}

Data penilaian kualitatif mendeskripsikan saran dan komentar dari masing-masing ahli dan calon pengguna produk yang kemudian digunakan sebagai acuan perbaikan produk. Penilaian secara kualitatif dari ahli BK antara lain: (1) pengecekan media DVD pelatihan secara umum; (2) pemilihan film terkait dengan topik yang dipilih; (3) pemilihan topik yang sesuai dengan tingkat perkembangan siswa SMP; (4) pengecekan kesiapan format pemutaran musik klasik pada media DVD pelatihan dan; (5) pemilihan sampul pada panduan pelatihan yang sesuai dengan tingkat jenjang SMP.

Penilaian deskrisptif dari uji ahli yang terakhir yaitu ahli TEP yang secara khusus memberikan penilaian deskriptif terhadap kemasan produk secara keseluruhan. Penilaian tersebut yaitu: (1) pemilihan sampul panduan seharusnya disesuaikan dengan tingkat perkembangan siswa SMP; (2) pemilihan film harus lebih diperhatikan, khususnya dalam hal durasi; (3) pemilihan topik juga harus disesuaikan dengan tingkat perkembangan siswa SMP.

Selain penilaian dari ahli, penilaian juga dilakukan oleh calon pengguna produk. Calon pengguna produk adalah tiga konselor sekolah di tiga SMP berbeda. Calon pengguna produk pertama dan kedua memberikan saran untuk menyederhanakan judul. Calon pengguna produk ketiga memberi saran untuk menyesuaikan sampul dengan tingkat perkembangan siswa dan masalah yang ada di dalamnya. Calon pengguna produk ketiga juga memberi masukan terkait kesalahan ketik dalam panduan. 
Secara keseluruhan, hasil pelaksanaan uji coba produk menunjukkan bahwa menurut ahli BK; ahli TEP; dan calon pengguna, produk panduan pelatihan keterampilan sikap empati sebagai pencegahan perilaku bullying siswa SMP merupakan produk yang memiliki tingkat keberterimaan dan kelayakan yang tinggi. Terkait dengan hal tersebut, produk panduan pelatihan keterampilan sikap empati layak untuk digunakan pada kegiatan pengembangan pribadi siswa untuk mencegah perilaku bullying. Selanjutnya, hasil penilaian dari uji coba tersebut ditindaklanjuti dengan revisi untuk menyempurnakan produk panduan pelatihan keterampilan sikap empati sebagai pencegahan perilaku bullying siswa SMP.

\section{PEMBAHASAN}

Kegiatan awal yang dilakukan sebelum mengembangkan produk adalah mengkaji hasil penelitian yang mengembangkan metode-metode untuk meningkatkan empati siswa dalam fungsi BK pada aspek pencegahan. Adapun hasil penelitian tersebut diantaranya adalah: melalui proyek kelompok (Lin \& Chuang, 2019); bermain peran (Latshaw, 2015; Reilly, Trial, Piver, \& Schaff, 2012); permainan (Nieh \& Wu, 2018); film (Auliyah \& Flurentin, 2016); buku (Salay, 2018); serta bibliokonseling (Asri \& Anggriana, 2016). Dari berbagai metode tersebut, teknik yang lebih banyak digunakan bertitik berat pada permainan dan konseling.

Hasil penyebaran need assessment dan wawancara kepada delapan konselor di lima sekolah Kota Malang menunjukkan kebutuhan yang tinggi terhadap metode layanan interaktif serta penggunaan media berupa video. Tingginya kebutuhan penggunaan media video dikarenakan video lebih praktis serta lebih aktif untuk mencapai target layanan untuk siswa (Anggraeni, 2010) dan efektif untuk meningkatkan kemampuan pemecahan masalah siswa (Utami, 2011).

Peningkatan empati yang efektif untuk mengurangi bullying (Stanbury, Bruce, Jain, \& Stellern, 2009), serta berdasarkan berbagai hasil kajian penelitian terdahulu terhadap pemilihan metode dan mempertimbangkan tingkat kebutuhan konselor, maka peneliti mengembangkan metode berbasis media video yang menggunakan teknik sinema edukasi untuk meningkatkan empati siswa SMP. Lebih lanjut, dalam perencanaan pengembangan produk ini peneliti melibatkan banyak kegiatan ice breaking di dalamnya. Asumsi penggunaan beragam ice breaking karena dalam melatihkan empati pada usia anak remaja, hendaknya menciptakan kondisi yang mampu menarik perhatian individu (Franken-Wendelstorf, Konrad, \& Schuchardt, 2014).

Produk yang telah dikembangkan kemudian dinilaikan pada ahli dan pengguna. Penilaian pada tiga ahli dan tiga calon pengguna terhadap produk menunjukkan kesepakatan sangat tinggi terhadap kebergunaan produk. Produk dinilai berguna sebab bersifat preventif, sehingga proses implementasinya lebih relevan digunakan untuk konselor sekolah dalam mengisi jam BK di kelas. Produk juga dianggap berguna karena mampu memenuhi kebutuhan akan panduan karena tingginya perilaku bullying di kalangan siswa SMP Kota Malang. Produk lain yang telah diterima untuk mencegah perilaku bullying di SMP adalah panduan pelatihan creative problem solving (Sukarno \& Handarini, 2016) dan keterampilan pengelolaan emosi (Irani, Handarini, \& Fauzan, 2018).

Dalam aspek penilaian kemenarikan yang menjabarkan butir-butir terkait kemenarikan tampilan luar produk dan kemenarikan isi, ketiga ahli dan ketiga calon pengguna sepakat bahwa produk menarik. Produk memenuhi aspek kemenarikan karena desain tata letak yang mampu menarik perhatian siswa serta sampul yang menunjukkan bullying mampu mewakili isi produk. Penggunaan gambar yang menarik mampu membuat orang tertarik (Baloglu \& McCleary, 1999). Selain gambar, tata letak dalam panduan yang bagus juga dapat membuat orang tertarik (Tiwasing, Sahachaisaeree, \& Hapeshi, 2014). Selain gambar, penggunaan media film juga membuat produk dinilai menarik. Penggunaan film diminati siswa karena mampu membuat siswa lebih tertarik; termotivasi; serta lebih mampu mengingat materi (Kosterelioglu, 2016).

Penilaian aspek ketepatan menjabarkan butir-butir terkait ketepatan kegunaan produk; ketepatan rancangan kegiatan produk; ketepatan isi buku materi; ketepatan penggunaan bahasa; dan ketepatan intervensi pada produk. Hasil penilaian ketiga ahli dan ketiga calon pengguna produk menunjukkan ketepatan produk masuk pada kategori kesepakatan sangat tinggi. Produk dinilai tepat sebab isi 
materi serta pemilihan film yang dipilih sesuai dengan usia anak SMP sehingga mudah untuk dipahami siswa. Film yang diurutkan mulai menampilkan bullying tingkat rendah ke bullying tinggi juga menjadikan produk tepat. Pengurutan ini dilakukan agar siswa lebih cepat memahami suatu topik (Chen, 2010).

Kepatutan produk yang terkait dengan persyaratan kompetensi calon pengguna produk; standar kode etik; dan pertanggungjawaban secara komprehensif dinilai ahli BK dan ahli TEP memiliki kepatutan yang tinggi. Kedua ahli sepakat bahwa produk telah memenuhi standar kode etik dan pertanggungjawaban konselor secara komprehensif.

Berdasarkan keberterimaan dan kelayakan produk yang telah dijelaskan, produk ini memiliki beberapa keunggulan. Keunggulan tersebut adalah produk ini dapat dijadikan alternatif untuk kegiatan pengembangan pribadi siswa. Beberapa keunggulan lain yang dimiliki produk yang telah dikembangkan adalah: (1) menggunakan intervensi kombinasi teknik sinema edukasi dan dialog socrates sebagai tahapan evaluasinya yang sifatnya lebih inovatif dan belum pernah dikembangkan pada ranah BK; (2) panduan dilengkapi dengan $D V D$ kumpulan film yang digunakan sebagai materi dalam memberikan pelatihan; (3) terdapat berbagai jenis ice breaking yang ada pada setiap sesi pertemuan pelatihan; dan (4) terdapat instrumen skala keterampilan empati yang sudah dikembangkan dan divalidasi, sehingga dapat digunakan untuk pretest (menjaring siswa) dan posttest (evaluasi).

\section{SIMPULAN}

Produk panduan pelatihan empati sebagai upaya preventif perilaku bullying untuk siswa SMP yang dikembangkan telah memenuhi penilaian dari para ahli dan pengguna, sehingga produk dinilai berguna; tepat; menarik; dan patut digunakan untuk siswa SMP. Saran ditujukan pada: (1) konselor sekolah agar menjadikan produk sebagai panduan kegiatan pengembangan diri siswa agar memiliki empati untuk mencegah perilaku bullying; (2) peneliti selanjutnya agar mengkaji produk lebih dalam untuk mengetahui keefektifan dari panduan pelatihan empati sebagai upaya preventif perilaku bullying siswa SMP.

\section{DAFTAR RUJUKAN}

Anggraeni, A. (2010). Penggunaan Media Film untuk Meningkatkan Motivasi Siswa Mengikuti Layanan Informasi Belajar dalam Pelayanan Bimbingan dan Konseling di Kelas VIII SMP N 1 Semarang. (Skripsi tidak diterbitkan). Universitas Negeri Semarang.

Arsenio, W. F., \& Lemerise, E. A. (2001). Varieties of Childhood Bullying: Values, Emotion Processes, and Social Competence. Social Development, 10(1), 59-73.

Arsyad, A. (2016). Media Pembelajaran. Bandung: Rajawali Press.

Asri, D. N., \& Anggriana, T. M. (2016). Efektivitas Bibliokonseling untuk Meningkatkan Empati Remaja di Rumah Pintar "Bunga Padi" Kecamatan Balerejo, Kabupaten Madiun. Counsellia: Jurnal Bimbingan Dan Konseling, 2(2).

Auliyah, A., \& Flurentin, E. (2016). Efektifitas Penggunaan Media Film untuk Meningkatkan Empati Siswa Kelas VII SMP. Jurnal Kajian Bimbingan dan Konseling, 1(2), 19-26. https:// doi.org/10.17977/um001v1i12016p019

Baloglu, S., \& McCleary, K. W. (1999). A Model of Destination Image Formation. Annals of Tourism Research, 26(4), 868-897. https://doi.org/10.1016/S0160-7383(99)00030-4

Chen, P.-H. (2010). Item Order Effects on Attitude Measures. (Disertasi tidak diterbitkan).University of Denver

Coloroso, B. (2007). Stop Bullying (Memutus Rantai Kekerasan Anak dari Prasekolah Hingga $S M U)$. Jakarta: Ikrar Mandiri Abadi.

Ediati, A. (2015). Profil Problem Emosi/Perilaku Pada Remaja Pelajar SMP-SMA Di Kota Semarang. Jurnal Psikologi, 14(2), 190-198. 
Franken-Wendelstorf, R., Konrad, M., \& Schuchardt, A. (2014). Serious Games and Multimedia Technology in Mobile Information Systems for Museums. Dalam Proceedings of the European Conference on Games-based Learning (Vol. 1, pp. 136-142).

Gall, M. D., Borg, W. R., \& Gall, J. P. (1996). Educational Research: An Introduction, 6th ed. White Plains, NY, England: Longman Publishing.

Gini, G., Albiero, P., Benelli, B., \& Altoè, G. (2007). Does Empathy Predict Adolescents' Bullying and Defending Behavior? Aggressive Behavior: Official Journal of the International Society for Research on Aggression, 33(5), 467-476.

Hurlock, E. B. (1999). Perkembangan Anak. Jakarta: Erlangga.

Irani, L. C., Handarini, D. M., \& Fauzan, L. (2018). Pengembangan Panduan Pelatihan Keterampilan Mengelola Emosi sebagai Upaya Preventif Perilaku Bullying Siswa Sekolah Menengah Pertama. Jurnal Kajian Bimbingan dan Konseling, 3(1), 22-32. https://doi.org/10.17977/ um001v3i12018p022

Kosterelioglu, I. (2016). Student Views on Learning Environments Enriched by Video Clips. Universal Journal of Educational Research, 4(2), 359-369.

Latshaw, B. A. (2015). Examining the Impact of a Domestic Violence Simulation on the Development of Empathy in Sociology Classes. Teaching Sociology, 43(4), 277-289.

Limarga, D. M. (2017). Penerapan Metode Bercerita dengan Media Audio Visual untuk Meningkatkan Kemampuan Empati Anak Usia Dini. Tunas Siliwangi: Jurnal Program Studi Pendidikan Guru PAUD STKIP Siliwangi Bandung, 3(1), 86-104.

Lin, C.-T., \& Chuang, S.-S. (2019). Using Team Projects for Making Short Films to Cultivate Students' Interdisciplinary Competencies. Interactive Learning Environments, 27(1), 103-117. https://doi.org/10.1080/10494820.2018.1451900

Miller, P. A., \& Eisenberg, N. (1988). The Relation of Empathy to Aggressive and Externalizing/ Antisocial Behavior. Psychological Bulletin, 103(3), 324-344.

Mufiqoh, A., Sugiharto, D. Y. P., \& Anni, C. T. (2018). The Effectiveness of Group Guidance with Film Media to Improve Students' Empathy and Social Interaction. Jurnal Bimbingan Konseling, $7(2), 96-100$.

Nieh, H.-P., \& Wu, W.-C. (2018). Effects of a Collaborative Board Game on Bullying Intervention: A Group-Randomized Controlled Trial. Journal of School Health, 88(10), 725-733. https://doi. org/10.1111/josh.12675

Papalia, D. E., Olds, S. W., \& Feldman, R. D. (2007). Human Development. McGraw-Hill.

Reilly, J. M., Trial, J., Piver, D. E., \& Schaff, P. B. (2012). Using Theater to Increase Empathy Training in Medical Students. Journal for Learning Through the Arts, 8(1), 1-10.

Rigby, K. (2002). New Perspectives on Bullying. Jessica Kingsley Publishers.

Salay, D. M. (2018). Walk in Their Shoes: How Picture Books and Critical Literacy Instruction Can Foster Empathy in First Grade Students. ProQuest LLC.

Stanbury, S., Bruce, M. A., Jain, S., \& Stellern, J. (2009). The Effects of an Empathy Building Program on Bullying Behavior. Journal of School Counseling, 7(2), 1-27.

Sukarno, T., \& Handarini, D. (2016). Pengembangan Panduan Pelatihan Creative Problem Solving untuk Mencegah Bullying di SMP. Jurnal Kajian Bimbingan dan Konseling, 1(2), 33-39. https://doi.org/10.17977/um001v1i12016p033

Tiwasing, W., Sahachaisaeree, N., \& Hapeshi, K. (2014). Design Goals and Attention Differentiations among Target Groups: A Case of Toy Packaging Design Attracting Children and Parents' Purchasing Decision. Design Principles and Practices, 7(1), 29-43.

Utami, N. W. (2011). Pengembangan Panduan Pelatihan Keterampilan Pemecahan Masalah (Problem Solving Skill) dengan Cinemeducation untuk Siswa SMP. (Tesis tidak diterbitkan). Universitas Negeri Malang. 